\title{
A Unified Framework to Integrate SPECT Perfusion Imaging with Dose-volume Metrics for Estimation of Radiation Pneumonitis
}

Research

Keywords:

Posted Date: October 14th, 2020

DOl: https://doi.org/10.21203/rs.3.rs-64363/v2

License: (c) (1) This work is licensed under a Creative Commons Attribution 4.0 International License. Read Full License 


\section{Abstract}

The authors have requested that this preprint be withdrawn due to author disagreement.

\section{Full Text}

The authors have withdrawn this preprint from Research Square. 